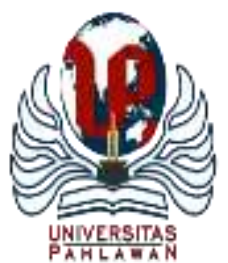

Edukatif : Jurnal Ilmu Pendidikan Volume 4 Nomor 1 Tahun 2022 Halm 1408 - 1416 EDUKATIF: JURNAL ILMU PENDIDIKAN

Research \& Learning in Education

https://edukatif.org/index.php/edukatif/index

\title{
Kemampuan Guru Sekolah Dasar dalam Mengembangkan Soal Tes Literasi Numerasi Berbasis Education for Sustainable Development
}

\author{
Widia Aprilianti ${ }^{1 凶}$, Ghullam Hamdu², Ahmad Mulyadiprana ${ }^{3}$ \\ Universitas Pendidikan Indonesia Kampus Daerah Tasikmalaya, Indonesia ${ }^{1,2,3}$ \\ E-mail : widiaaprilianti@upi.edu ${ }^{1}$, ghullamh2012@ upi.edu $^{2}, \underline{\text { ahmadmulyadiprana@upi.edu }}^{3}$
}

\begin{abstract}
Abstrak
Penilaian menggunakan soal tes literasi numerasi diyakini mampu mengembangkan keterampilan memecahkan masalah tingkat tinggi siswa. Namun guru di sekolah belum mampu membuat soal yang sesuai. Tujuan dari penelitian ini untuk menganalisis kemampuan guru sekolah dasar dalam mengembangkan soal tes literasi numerasi berbasis ESD. Jenis penelititan ini yaitu kualitatif. Sumber data utama meliputi 3 guru kelas 6 di Sekolah Dasar yang berbeda. Sumber data pendukung berupa dokumen soal-soal tes tertulis. Instrumne yang digunakan yaitu pedoman wawancara, lembar observasi, lembar studi dokumentasi dan lembar kuisioner. Data dikumpulkan dengan teknik wawancara dan dokumentasi. Teknik yang digunakan untuk menganalisis data yaitu analisis deskriptif kualitatif dan kuantitatif. Hasil dari penelitian menunjukan bahwa sebagian besar guru sudah membuat soal tes literasi numerasi tetapi belum maksimal dikarenakan sulitnya menentukan KKO (Kata Kerja Operasional) dan memilih stimulus. Disamping itu, terkait pembelajaran berbasis ESD belum dimengerti secara konsepnya, namun pelaksanaan di lapangan sudah terealisasikan. Dapat disimpulkan bahwa tingkat kemampuan guru sekolah dasar dalam mengembangkan soal tes literasi numerasi berbasis ESD masih rendah dan perlu adanya pembinaan serta pelatihan.
\end{abstract}

Kata Kunci: kemampuan, guru, soal tes, literasi numerasi, esd.

\section{Abstract}

Assessment using numeracy literacy test questions is believed to be able to develop students' high-level problem solving skills. However, teachers at schools have not been able to make appropriate questions. The purpose of this study was to analyze the ability of elementary school teachers to develop ESD-based numeracy literacy test questions. This type of research is qualitative. The main data sources include 5 6th grade teachers in different Primary Schools. Sources of supporting data in the form of documents written test questions. The instruments used are interview guides, observation sheets, documentation study sheets and questionnaire sheets. Data were collected by interview and documentation techniques. The technique used to analyze the data is descriptive qualitative and quantitative analysis. The results of the study show that most teachers have made numeracy literacy test questions but have not been maximized due to the difficulty of determining KKO (Operational Verbs) and choosing a stimulus. In addition, related to ESD-based learning, the concept has not been understood, but the implementation in the field has been realized. So it can be concluded that the level of ability of elementary school teachers in developing ESD-based numeracy literacy test questions is still low and there is a need for coaching and training.

Keywords: ability, teacher, test, numeration literacy, esd.

Copyright (c) 2022 Widia Aprilianti, Ghullam Hamdu, Ahmad Mulyadiprana

$\triangle$ Corresponding author

Email : widiaaprilianti@upi.edu

DOI : https://doi.org/10.31004/edukatif.v4i1.2139

ISSN 2656-8063 (Media Cetak)

ISSN 2656-8071 (Media Online) 
1409 Kemampuan Guru Sekolah Dasar dalam Mengembangkan Soal Tes Literasi Numerasi Berbasis Education for Sustainable Development - Widia Aprilianti, Ghullam Hamdu, Ahmad Mulyadiprana

DOI: https://doi.org/10.31004/edukatif.v4i1.2139

\section{PENDAHULUAN}

Sekolah menjadi agen utama dalam mendukung pembangunan berkelanjutan (Darmaji et al., 2019). Untuk dapat membentuk karakter siswa yang perduli pada lingkungan, maka seorang guru harus dapat menerapkan prinsip-prinsip ESD dalam pembelajaran (Didham \& Ofei-Manu, 2020). ESD (Education Sustainable for Development) secara umum dapat dipahami sebagai pendidikan yang memberdayakan siswa supaya dapat mengambil keputusan berdasarkan informasi yang mereka peroleh serta senantiasa bertindak secara bertanggung jawab terhadap lingkungan, ekonomi dan masyarakat untuk generasi sekarang dan masa depan dengan selalu menghormati keragaman budaya yang ada (Wijayanti \& Christian Relmasira, 2019). Sehingga guru sangat dituntut untuk bisa menguasai konsep ini yang nantinya akan diajarkan kepada siswa. Sejalan dengan hal tersebut, saat ini semua sekolah di Indonesia sudah menerapkan kurikulum 2013. Kurikulum 2013 mengalami revisi pada tahun 2017. Hal itu disebabkan karena pelaksanaan pembelajaran harus memuat beberapa kompetensi yang salah satunya yaitu kemampuan literasi. Kemampuan literasi itu memuat 6 aspek literasi dasar yaitu literasi baca dan tulis, literasi numerasi, literasi sains, literasi finansial, literasi digital dan literasi budaya.Kemampuan literasi tersebut sangat penting dimiliki dan dikuasai oleh siswa supaya dapat berkompetensi pada abad ke-21. Dari beberapa kemampuan tersebut, yang paling harus dikuasai oleh siswa yaitu kemampuan literasi numeras, karena dengan kemampuan ini kita di ajarkan untuk tidak semena-mena dalam mengambil keputusan. Selain itu, kemampuan literasi numerasi juga dapat membantu siswa untuk dapat berfikir rasional, sistematis, kritis dalam menyelesaikan masalah dan mengambil keputusan dalam berbagai konteks. Banyak sekali permasalahan lokal maupun global yang menuntut seseorang untuk dapat kritis dalam memilih informasi dan mengambil keputusan. Oleh karena itu, guru sebagai seorang pendidik diharapkan dapat membantu dalam mengembangkan keterampilan dan kemampuan literasi numerasi siswa. Dengan demikian fokus penelitian ini berkaitan dengan kompetensi literasi numerasi.

Berdasarkan hasil Programme for International Student Assesment (PISA) tentang Pendidikan di Indonesia pada tahun 2015 menunjukkan bahwa kualitas sistem pendidikan di Indonesia menduduki peringkat ke-62 dari 72 negara peserta seluruhnya akan tetapi, menurut hasil PISA tahun 2018 penilaian di Indonesia dikatakan turun apabila dibandingkan dengan hasil PISA tahun 2015. Menurut Pusat Penilaian Pendidikan Bidang Assesmen Balibang Kemendikbud, hasil PISA tahun 2015 skor yang di dapat Indonesia dalam kemampuan mambaca 397, kemampuan matematika 386 dan kemampuan kinerja sains 403. Sedangkan hasil PISA tahun 2018 menunjukan kemampuan kinerja membaca mendapat skor 371, kemampuan matematika 379, dan kemampuan kinerja sains 396. Hal ini menunjukan bhawa perkembangan pendidikan di Indonesia masih jauh tertinggal dibandingkan dengan negara lain di dunia. Oleh karena itu, Kemendikbud menerapkan program terbaru yang disebut dengan Assesmen Nasional sebagai pengganti Ujian Nasional (AKM) sebagai pengganti Ujian Naional yang mulai diterapkan pada tahun 2021. AKM adalah penilaian kompetensi mendasar yang dibutuhkan seluruh siswa agar dapat mengembangkan kemampuan diri sendiri serta berperan aktif dalam masyarakat pada kegiatan yang bernilai positif.AKM digunakan untuk mengukur kemampuan kognitif siswa dimana aspek yang diukur adalah kemampuan membaca dan literasi numerasi. Dalam rangka mengembangkan kemampuan literasi numerasi siswa, guru dapat menggunakan Taksonomi Bloom sebagai landasannya. Guru memberikan pertanyaan-pertanyaan yang berkaitan dengan pemikiran tingkat tinggi (High Order Thinking Skills) meliputi analisis, sintesis, dan mengevaluasi (Khan \& Masood, 2015). Oleh karena itu, untuk menunjang keprofesionalannya sebagai guru maka tugas guru bukan hanya mendidik dan membimbing saja pada saat pembelajaran, tetapi harus mampu untuk melakukan penilaian kepada siswa (Gorghiu et al., 2011). Salah satu caranya yaitu dengan terampil membuat soal tes tertulis yang baik dan tepat untuk digunakan.

Penilaian hasil belajar siswa merupakan kegiatan menghimpun dan mengolah informasi berdasarkan hasil belajar siswa dengan tujuan untuk mengetahui perkembangan pembelajarannya serta untuk 
menyimpulkan hasil pencapaian pembelajaran siswa (Suparmi, 2019). Salah satu alat penilaian yaitu berupa tes. Tes di definisikan sebagai cara atau prosedur yang dapat digunakan untuk mengukur dan menilai dalam bidang pendidikan. Oleh karena itu, seorang pendidikan harus memiliki kemampuan dalam menilai hasil belajar siswanya. Namun, pada pelaksanaannya di lapangan masih banyak guru-guru sekolah dasar yang masih kesulitan dalam pembuatan dan pengembangan soal tes tipe HOTS. Hal ini dibuktikan dengan hasil penelitian yang dilakukan oleh Winarti, yang menyebutkan bahwa "kemampuan guru dalam membuat soal berdasarkan kurikulum 2013 berada pada kategori cukup, hal ini dikarenakan guru mengalami kesulitan membuat soal HOTS dan menentukan perbedaan tingkat kognitif dari suatu pertanyaan".

Tes yang sering digunakan oleh guru yaitu berupa tes tertulis berbentuk pilihan ganda dan uraian. Dalam pelaksanaanya tes tertulis dilakukan dengan cara menjawab soal ujian pada kertas ujian secara tertulis baik dengan tulisan tangan maupun komputer. Tes ini dapat dikembangkan sesuai dengan keterampilan yang akan diukur yaitu kemampuan literasi numerasi dengan indikatornya meliputi analisis, sintesis, memecahkan masalah, menyimpulkan dan evaluasi. Indicator-indikator tersebut termasuk ke dalam kriteria HOTS. Untuk mengetahui HOTS pada siswa maka diperlukan sebuah penilaian yang dapat mengukur kemampuan tersebut. Dengan demikian, tujuan penelitian ini yaitu untuk menganalisis kemampuan guru sekolah dasar dalam mengembangkan soal tes literasi numerasi berbasis ESD serta factor penyebabnya. Hasil penelitian ini diharapkan dapat memberikan rekomendasi berkaitan dengan memberikan contoh yang tepat bagi guru SD dalam mengembangkan soal tes yang dapat menggali kemampuan literasi numerasi berbasis ESD.

\section{METODE PENELITIAN}

Penelitian ini menggunakan metode deskriptif kualitatif. Metode ini menggunakan alur induktif yaitu penelitian diawali dengan penjelasan suatu proses atau peristiwa sehingga di akhir dapat ditarik generalisasi sebagai suatu kesimpulan (Nurmalasari \& Erdiantoro, 2020). Sumber data utama dalam penelitian ini melibatkan 3 guru kelas VI, dengan rincian 1 guru mengajar di Kota Tasikmalaya, 1 guru mengajar di Kabupaten Bandung, dan 1 guru mengajar di Kota Jakarta Timur. Adapun sumber data pendukung yaitu soalsoal tes tertulis di kelas tinggi. Instrument yang peneliti gunakan yaitu pedoman wawancara, lembar observasi, lembar studi dokumentasi dan lembar kuisioner .pedoman wawancara yang dibuat oleh peneliti akan ditanyakan kepada guru dengan pertanyaan sebanyak 28 butir. Lembar studi dokumentasi yaitu dokumendokumen yang hendak diteliti berupa soal-soal. Lembar kuisioner berisi tentang pertanyaan karakteristik, identitas narasumber dan pertanyaan tertulis mengenai hal-hal yang diketahui oleh responden mengenai pengembangan soal tes. Instrument-instrumen tersebut di validasi secara FGD dan oleh Expert Judgement sebagai validator.

Berdasarkan pandangan tersebut peneliti mengumpulkan data menggunakan wawancara, expert judgement (Penilaian Ahli), dan mengumpulkan dokumen. Pertama, peneliti menyusun kisi-kisi dan instrument wawancara yang memuat 28 pertanyaan serta kisi-kisi lembar validasi soal baik pilihan ganda dan essay, kemudian dilakukan expert judgement (Penilaian Ahli) untuk memvalidasi instrument wawancara. Tujuan penilaian ahli yaitu untuk menguji kelayakan instrument yang telah dirancang. Selanjutnya wawancara dilakukan oleh peneliti kepada guru sekolah dasar yang telah ditentukan. Wawancara dimaksudkan untuk dapat mengidentifikasi masalah yang berhubungan dengan perencanaan dan penerapan soal tes tertulis yang ada di sekolah. Setelah itu peneliti mengumpulkan dokumen berupa soal-soal tes yang ada di sekolah tersebut untuk dianalisis menggunakan kisi-kisi lembar validasi soal. 
1411 Kemampuan Guru Sekolah Dasar dalam Mengembangkan Soal Tes Literasi Numerasi Berbasis Education for Sustainable Development - Widia Aprilianti, Ghullam Hamdu, Ahmad Mulyadiprana

DOI: https://doi.org/10.31004/edukatif.v4i1.2139

Tabel 1.kisi-kisi instrument wawancara

\begin{tabular}{|c|c|}
\hline Fokus Penelitian & Indikator \\
\hline \multirow{5}{*}{$\begin{array}{l}\text { Pemahaman terhadap } \\
\text { Penilaian } \\
\text { Kurikulum } 2013\end{array}$} & Pemahaman mengenai tes tertulis pada Kurikulum 2013 \\
\hline & Pendapat terhadap kebijakan Kurikulum 2013 perihal tes tertulis \\
\hline & Pemahaman kebijakan sekolah dalam mengatur pelaksanaan tes tertulis \\
\hline & Fakta pelaksanaan tes tertulis dalam pembelajaran tematik di sekolah \\
\hline & Pendapat mengenai urgensi tes tertulis yang dilaksanakan di sekolah \\
\hline \multirow{5}{*}{$\begin{array}{l}\text { Pemahaman Mengenai } \\
\text { Pengembangan Soal } \\
\text { Tes Tertulis }\end{array}$} & Fakta mengenai pengembangan soal yang dilakukan \\
\hline & $\begin{array}{l}\text { Langkah-langkah yang dilakukan dalam pembuatan atau pengembangan } \\
\text { soal tes }\end{array}$ \\
\hline & $\begin{array}{l}\text { Fakta kesesuaian soal tes tertulis dengan kemampuan literasi dan numerasi } \\
\text { siswa, tujuan pembelajaran serta indicator yang telah disusun. }\end{array}$ \\
\hline & $\begin{array}{l}\text { Fakta mengenai kendala yang di rasakan dalam pembuatan dan } \\
\text { pengembangan soal tes tertulis serta cara mengatasi kendala tersebut. }\end{array}$ \\
\hline & Pemahaman mengenai Taksonomi Bloom \\
\hline \multirow{3}{*}{$\begin{array}{l}\text { Pengembangan } \\
\text { Tes Loal } \\
\text { Numerasi berbasis } \\
\text { ESD }\end{array}$} & $\begin{array}{l}\text { Pemahaman mengenai ESD yang dikaitkan dengan pengembangan soal tes } \\
\text { berbasis ESD }\end{array}$ \\
\hline & $\begin{array}{l}\text { Tanggapan mengenai soal tes yang dikembangkan didasarkan pada literasi } \\
\text { dan numerasi berbasis ESD }\end{array}$ \\
\hline & $\begin{array}{l}\text { Tanggapan mengenai soal tes tertulis literasi dan numerasi yang } \\
\text { dikembangkan melalui keterampilan berpikir tingkat tinggi (HOTS) }\end{array}$ \\
\hline \multirow{3}{*}{$\begin{array}{l}\text { Pelaksanaan } \\
\text { Pengolahan Hasil Tes }\end{array}$} & Fakta pengolahan skort es atau hasil tes yang sering dilakukan di sekolah \\
\hline & Pemahaman mengenai cara mengolah skor mentah dari hasil tes \\
\hline & Langkah-langkah yang dilakukan dalam mengolah skor dari hasil tes \\
\hline \multirow{3}{*}{$\begin{array}{l}\text { Pengolahan Hasil Tes } \\
\text { melalui Analisis } \\
\text { Pemodelan Rasch }\end{array}$} & Pengetahuan tentang pengolahan skor dengan analisis pemodelan Rasch \\
\hline & $\begin{array}{l}\text { Fakta pengolahan skor atau hasil tes melalui analisis pemodelan Rasch di } \\
\text { sekolah }\end{array}$ \\
\hline & Urgensi pengolahan skor mentah melalui analisis pemodena Rasch \\
\hline
\end{tabular}

Teknik yang digunakan untuk menganalisis data yaitu analisis deskriptif dan kuantitatif. Pada penelitian ini menggunakan teknik model Miles dan Huberman. Langkah-langkah teknik analisis model ini yaitu data collection, data display, conclusions: drawing/verifying dan data condensation (Darma Putra \& Sujana, 2020). Selanjutnya uji keabsahan penelitian ini dilakukan melalui pengamatan dan triangulasi.

\section{HASIL DAN PEMBAHASAN PENELITIAN}

\section{HASIL}

Penentuan responden dilakukan melalui pengambilan data berdasarkan identitas tempat mengajar, usia, dan jabatan/golongan dari guru SD. Identitas ini diperoleh dengan mengisi isian melalui google form terkait identitas serta karakteristik responden yang terlibat dalam penelitian ini. Berdasarkan hasil analisis data Adapun pemahaman guru mengenai penilaian dalam kurikulum 2013 disajikan pada tabel 1 . 
1412 Kemampuan Guru Sekolah Dasar dalam Mengembangkan Soal Tes Literasi Numerasi Berbasis Education for Sustainable Development - Widia Aprilianti, Ghullam Hamdu, Ahmad Mulyadiprana

DOI: https://doi.org/10.31004/edukatif.v4i1.2139

Tabel 1. Pemahaman guru mengenai penilaian dalam kurikulum 2013, esd, dan literasi numerasi

\begin{tabular}{cccc}
\hline Guru & $\begin{array}{c}\text { Pemahaman terhadap } \\
\text { penilaian dalam kurikulum }\end{array}$ & $\begin{array}{c}\text { Pemahaman } \\
\text { mengenai konsep } \\
\text { ESD }\end{array}$ & $\begin{array}{c}\text { Pemahaman mengenai } \\
\text { keterampilan literasi numerasi }\end{array}$ \\
\hline A & Sangat Baik & Baik & Cukup \\
\hline B & Baik & Kurang & Cukup \\
\hline C & Baik & Kurang & Cukup \\
\hline
\end{tabular}

Sejalan dengan hasil analisis data, kebijakan terkait kurikulum 2013 yang menerapkan penilaian menggunakan soal tes tertulis disetujui oleh 3 guru dan meninginginkan supaya tetap diadakan. Di masingmasing SD tempat 3 guru mengajar sendiri soal tes tertulis yang diberikan kepada sisiwa bentuknya sama berupa soal pilihan ganda, isian singkat dan uraian. Untuk pelaksanaannya juga sama, PTS (Penilaian Tengah Semester) dilaksanakan setiap 3 bulan sekali dan PAS (Penilaian Akhir Semester) dilaksanakan setiap 6 bulan sekali, namun untuk ulangan harian diserahkan kepada masing-masing guru kelas.

Berdasarkan hasil wawancara, semua guru sudah berusaha membuat soal tes literasi numerasi atau HOTS namun semuanya belum maksimal, soal yang di buatnya pun masih di dominasi oleh soal dengan kualitas LOTS (Low Order Thingking Skill). Kesulitan yang dialami mayoritas guru ini dikarenakan sulitnya menentukan stimulus dan KKO (Kata Kerja Operasional).

Untuk mengatasi masalah tersebut guru melihat contoh soal-soal sebagai bahan referensi. Langkahlangkah dalam pembuatan soal oleh guru pun sangat beragam, ada yang melihat pada materi pembelajaran terlebih dahulu maupun KD atau tujuan pembelajaran, dilanjutkan dengan membuat kisi-kisi, soal dan kunci jawaban. Setelah siswa menjawab soal, 3 guru mengaku melakukan analisis terhadap hasil jawaban siswa untuk mengetahui siswa mana yang harus melaksanakan perbaikan dan pengayaan.
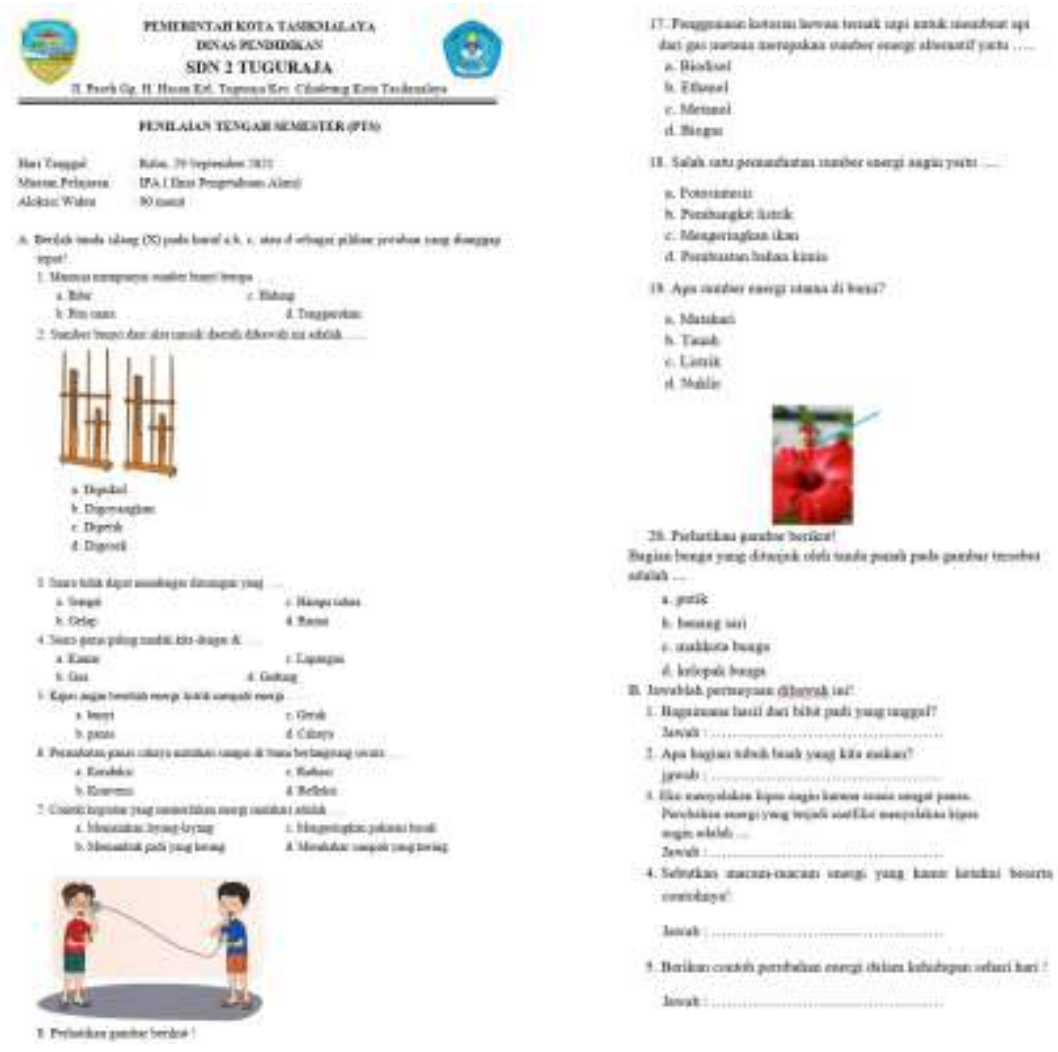

Gambar 1. Contoh soal di sekolah dasar 
Berdasarkan kuesioner dan wawancara dpat diketahui bahwa karakteristik guru berbeda-beda mempengaruhi pemahamannya terkait penilaian yang diatur dalam kurikulum 2013. Dari hasil kuesioner dan jawaban wawancara terlihat bahwa guru yang sudah pernah mengikuti pelatihan profesi terutama mengenai kurikulum 2013 lebih paham terkait kebijakan yang mengatur penilaian soal tes tertulis dalam kurikulum tersebut. Guru yang belum sama sekali mengikuti pelatihan masih belum terlalu memahaminya. Penilaian dalam kurikulum 2013 lebih holistic dan tegas dibandingkan kurikulum KTSP. Kurikulum 2013 ini mengharapkan supaya guru dapat melakukan penilaian yang dapat melibatkan ketiga ranah domain yaitu kognitif, afektif dan psikomotor secara seimbang sesuai dengan tujuan yang hendak diukur dari masingmasing ranah tersebut (Setiadi, 2016; Tiara \& Sari, 2019).

\section{PEMBAHASAN}

Semua guru merespon positif terhadap kebijakan penerapan soal tes tertulis karena merasa sangat penting untuk mengukur tingkat pengetahuan siswa terhadap materi yang telah disampaikan pada saat pembelajaran. Selain itu juga dapat melatih siswa dalam memecahkan suatu masalah. Penilaian menggunakan tes sendiri memiliki tujuan untuk memberikan umpan balik (feedback), menentukan pembelajaran selanjutnya, diagnostic kesulitan belajar dan miskonsepsi yang dialami oleh siswa, melihat kemajuan belajar dan sebagai alat evaluasi.

Penilaian menggunakan soal tes tertulis yang ada di masing-masing sekolah ternyata sama yaitu biasanya menggunakan soal tes bentuk pilihan ganda, isian singkat dan uraian. Tes tertulis sendiri merupakan tes soal yang jawabannya menggunakan berbentuk tulisan. Dalam menjawab soal tes tertulis, siswa tidak hanya merespon jawaban dalam bentuk kegiatan menulis tetapi bisa juga dengan mewarnai, memberi tanda, grafik, dll. Soal tes yang dibuat guru untuk menilai pengetahuan siswa meliputi soal pilihan ganda, essay, menjodohkan, kolom isian dan benar salah (Bazvand et al., 2018). Bentuk soal ini memudahkan guru dalam melakukan proses standarisasi karena berapapun banyak jumlahnya jawaban akan tetap sama (Zulkifli, 2018). Dengan demikian dapat diketahui bahwa penggunaan soal tes tertulis di sekolah dasar masih kurang bervariasi.

Sejalan dengan itu, ke-3 guru sudah memahami makna dari kemampuan literasi numerasi secara umum, namun belum memahami maknanya secara khusus dan detail.Semua guru juga dapat memahami bahwa kemampuan literasi numerasi erat kaitannya dengan HOTS karena bisa membantu siswa dalam memecahkan suatu masalah, dimana kemampuan ini terdiri dari level 1-6. Kemampuan literasi numerasi melibatkan seperangkat keterampilan dan disposisi yang di mobilisasi untuk menyelesaikan suatu masalah, mengambil keputusan dan berinteraksi dengan orang lain. Karena ada level tersebut sudah mencakup berbagai keterampilan mengenai analisis, sintesis, pemecahan masalah, inferensi dan evaluasi, maka keterampilan tersebut merupakan bagian dari tingkatan HOTS (Leder, 2018; Putranta \& Supahar, 2019; Sagala \& Andriani, 2019).

Terkait pengembangan soal semua guru sudah berusaha mengembangkan soal tes tertulis untuk mengukur kemampuan literasi numerasi siwa, apalagi sekarang sedang marak mengenai tes tentang AKM (Assesment Kompetisi Minimum) yang di gaungkan oleh pemerintah, namun mayoritas soal yang telah dikembangkan tidak cukup banyak dan masih di dominasi oleh soal-soal dengan taraf berpikir rendah. Hal ini dibuktikan dengan contoh soal yang ada, soal jarang sekali diawali dengan stimulus serta pemilihan pertanyaan yang diajukan hanya sebatas pertanyaan untuk menggali ingatan siswa.Kendala yang dialami oleh guru ini dikarenakan sulitnya menentukan KKO (Kata Kerja Operasional) yang hendak mengukur tingkat kemampuan literasi numerasi siswa serta sulit dalam memilih stimulus sehingga kadang tidak sesuai dengan pertanyaan yang diajukan kepada siswa. Kreativitas seorang guru dapat menentukan variasi dalam stimulus yang digunakan (Pratama \& Retnawati, 2018; Yusoff \& Seman, 2018). Stimulus merupakan hal yang penting dalam menyusun soal-soal bertipe HOTS. Stimulus ini dapat diambil dari isu-isu global seperti ekonomi, 
Pendidikan, sosial, teknologi dan kesehatan. Bisa juga diambil dari persoalan lingkungan sekitar seperti budaya, adat dan kelebihan dari suatu wilayah.

Berdasarkan langkah-langkah yang dilakukan dalam pembuatan soal tidaklah sama, ada guru yang membuat soal dengan menentukan KD dan indicator terlebih dahulu ada juga yang membuat soal diawali dengan langsung berfokus pada tujuan dan materi pembelajaran yang hendak dicapai oleh siswa. Hanya beberapa guru yang sekolah dasar yang di wawancarai yang membuat kisi-kisi soal. Seharusnya soal tes tertulis HOTS dikembangkan melalui beberapa tahapan yang disesuaikan dengan kebutuhan dari penyusun soal. Tahapan-tahapan dalam Menyusun soal HOTS yakni: 1) menganalisis KD untuk dibuat soal HOTS, 2) membuat kisi-kisi soal, 3) memilih stimulus yang kontekstual dan menarik bagi siswa, 4) menulis butir soal sesuai dengan kisi-kisi soal, 5) membuat pedoman penskoran(Widana, 2020).

Sejalan dengan itu, setelah mengerjakan soal tes yang diberikan, hasil jawbaan siswa hendaknya dianalisis secara akurat supaya kemampuan siswa dapat terukur dengan baik serta dapat mengukur kelayakan soal tes yang telah dibuat (Hassan et al., 2016; Tanudjaya \& Doorman, 2020). Adapun hasil tes yang baik apabila memenuhi aspek validitas dan reliabilitas instrument, sehingga dapat dipercaya dan layak untuk digunakan. Namun, kenyatannya di lapangan, walaupun semua guru mengaku melakukan analisis terhadap hasil tes tetapi masih tidak akurat karena cenderung bersifat subjektif. Penggunaan aplikasi khusus untuk menganalisis tidak digunakan oleh guru dikarenakan kendala waktu yang sangat menyita dan kurang pahamnya penggunaan aplikasi semacam itu.

Di sisi lain terkait pembelajaran program berbasis ESD sendiri, berdasarkan penelitian hanya 1 guru yang mengetahui istilah tersebut, 2 guru lainnya sama sekali belum pernah mendengar istilah tersebut. ESD ini dikenalkan pada bidang Pendidikan sebegai pendekatan dalam pembelajaran dalam rangka mendukung program pembangunan berkelanjutan (Listiawati, 2013). Hal tersebut bisa saja disebabkan karena kurikulum 2013 pada mata pelajaran nasional tidak secara langsung menyatakan komitmen terhadap ESD, tetapi Pendidikan nasional di Indonesia didedikasikan pada aspek pembangunan nasional. Sehingga konsep tersebut belum banyak dipahami olehguru. Guru hanya mengetahui pembelajaran berkelanjutan berbasis lingkungan, sosial, dan ekonomi saja belum mengajarkan untuk berkelanjutan di masa yang akan datang. Dengan demikian soal tes literasi numerasi berbasis ESD juga sepertinya minim jumlahnya.

Adapun yang perlu diperbaiki dari soal-soal yang ada di sekolah dasar saat ini yaitu dengan menambahkan jumlah soal tipe HOTS untuk melatih kemampuan literasi numerasi siswa. Ke-3 guru tersebut memiliki ide kedepannya dalam mengembangkan soal HOTS yaitu dengan penggunaan stimulus yang lebih bervariasi berupa skema, gambar dan infografis, grafik, diagram, dll. Stimulus yang disajikan hendaknya menarik dan kontekstual, stimulus ini dapat diambil dari isu-isu global contohnya masalah teknologi informasi, sains, ekonomi, kesehatan, pendidikan dan infrastruktur (Ichsan et al., 2019). Hasil dari penelitian ini dapat digunakan sebagai rujukan dalam mengetahui kemampuan guru sekolah dasar dalam mengembangkan soal tes literasi numerasi.

\section{KESIMPULAN}

Kemampuan guru dalam mengembangkan soal tes literasi numerasi atau soal tipe HOTS masih rendah. Para guru perlu diberikan contoh yang tepat mengenai pengembangan soal tes yang dapat menggali kemampuan literasi numerasi. Terkait pengembangan soal tes dengan pembelajaran berbasis ESD dapat dilakukan secara beriringan. Memberikan pelatihan yang sesuai antara pengembangan pembelajaran ESD dan asesmen yang sesuai. lingkup tersebut merupakan upaya untuk memperkaya pengetahuan guru yang perlu banyak pengalaman dalam melihat contoh-contoh soal tes literasi numerasi sebagai referensi. 
1415 Kemampuan Guru Sekolah Dasar dalam Mengembangkan Soal Tes Literasi Numerasi Berbasis Education for Sustainable Development - Widia Aprilianti, Ghullam Hamdu, Ahmad Mulyadiprana DOI: https://doi.org/10.31004/edukatif.v4i1.2139

\section{DAFTAR PUSTAKA}

Bazvand, A. D., Khorram, A., \& Mirsalari, S. A. (2018). Establishing An Argument-Based Validity Approach For A Low-Stake Test Of Collocational Behavior. Journal Of English Language Teaching And Learning, 10(22), 27-48.

Darma Putra, I. G., \& Sujana, I. W. (2020). Hasil Belajar IPS Menggunakan Kolaborasi Model Discovery Learning Berbasis Media Animasi. Journal of Education Technology, 4(2), 103. Https://Doi.Org/10.23887/Jet.V4i2.25099

Darmaji, Kurniawan, D. A., Astalini, Lumbantoruan, A., \& Samosir, S. C. (2019). Mobile Learning In Higher Education For The Industrial Revolution 4.0: Perception And Response Of Physics Practicum. International Journal Of Interactive Mobile Technologies, 13(9), 4-20. Https://Doi.Org/10.3991/Ijim.V13i09.10948

Didham, R. J., \& Ofei-Manu, P. (2020). Adaptive Capacity As An Educational Goal To Advance Policy For Integrating DRR Into Quality Education For Sustainable Development. International Journal Of Disaster Risk Reduction, 47(April), 101631. Https://Doi.Org/10.1016/J.Ijdrr.2020.101631

Gorghiu, L. M., Gorghiu, G., Bîzoi, M., \& Suduc, A. M. (2011). The Electronic Book - A Modern Instrument Used In Teachers' Training Process. Procedia Computer Science, 3, 563-567. Https://Doi.Org/10.1016/J.Procs.2010.12.093

Hassan, S. R., Rosli, R., \& Zakaria, E. (2016). The Use Of I-Think Map And Questioning To Promote HigherOrder Thinking Skills In Mathematics. Creative Education, 07(07), 1069-1078. Https://Doi.Org/10.4236/Ce.2016.77111

Ichsan, I. Z., Sigit, D. V., Miarsyah, M., Ali, A., Arif, W. P., \& Prayitno, T. A. (2019). HOTS-AEP: Higher Order Thinking Skills From Elementary To Master Students In Environmental Learning. European Journal Of Educational Research, 8(4), 935-942. Https://Doi.Org/10.12973/Eu-Jer.8.4.935

Khan, F. M. A., \& Masood, M. (2015). The Effectiveness Of An Interactive Multimedia Courseware With Cooperative Mastery Approach In Enhancing Higher Order Thinking Skills In Learning Cellular Respiration. Procedia - Social And Behavioral Sciences, 176, 977-984. Https://Doi.Org/10.1016/J.Sbspro.2015.01.567

Leder, S. (2018). Education For Sustainable Development And Argumentation. January, 55-88. Https://Doi.Org/10.1007/978-981-13-2369-0_3

Listiawati, N. (2013). Pelaksanaan Pendidikan Untuk Pembangunan Berkelanjutan Oleh Beberapa Lembaga. Jurnal Pendidikan Dan Kebudayaan, 19(3), 430. Https://Doi.Org/10.24832/Jpnk.V19i3.302

Nurmalasari, Y., \& Erdiantoro, R. (2020). Perencanaan Dan Keputusan Karier: Konsep Krusial Dalam Layanan BK Karier. Quanta, 4(1), 44-51. Https://Doi.Org/10.22460/Q.V1i1p1-10.497

Pratama, G. S., \& Retnawati, H. (2018). Urgency Of Higher Order Thinking Skills (HOTS) Content Analysis In Mathematics Textbook. Journal Of Physics: Conference Series, 1097(1). Https://Doi.Org/10.1088/1742-6596/1097/1/012147

Putranta, H., \& Supahar. (2019). Synthesis Of The Cognitive Aspects' Science Literacy And Higher Order Thinking Skills (HOTS) In Chapter Momentum And Impulse. Journal Of Physics: Conference Series, 1397(1). Https://Doi.Org/10.1088/1742-6596/1397/1/012014

Sagala, P. N., \& Andriani, A. (2019). Development Of Higher-Order Thinking Skills (HOTS) Questions Of Probability Theory Subject Based On Bloom's Taxonomy. Journal Of Physics: Conference Series, 1188(1). Https://Doi.Org/10.1088/1742-6596/1188/1/012025

Setiadi, H. (2016). Pelaksanaan Penilaian Pada Kurikulum 2013. Jurnal Penelitian Dan Evaluasi Pendidikan, 20(2), 166-178. Https://Doi.Org/10.21831/Pep.V20i2.7173

Suparmi, N. W. (2019). Hasil Belajar Pemahaman Konsep Dan Berpikir Kreatif Siswa Dalam Pembelajaran Inkuiri Bebas Dan Inkuiri Terbimbing. Journal of Education Technology, 2(4), 192. 
1416 Kemampuan Guru Sekolah Dasar dalam Mengembangkan Soal Tes Literasi Numerasi Berbasis Education for Sustainable Development - Widia Aprilianti, Ghullam Hamdu, Ahmad Mulyadiprana

DOI: https://doi.org/10.31004/edukatif.v4i1.2139

Https://Doi.Org/10.23887/Jet.V2i4.16548

Tanudjaya, C. P., \& Doorman, M. (2020). Examining Higher Order Thinking In Indonesian Lower Secondary Mathematics Classrooms. Journal On Mathematics Education, 11(2), 277-300. Https://Doi.Org/10.22342/Jme.11.2.11000.277-300

Tiara, S. K., \& Sari, E. Y. (2019). Analisis Teknik Penilaian Sikap Sosial Siswa Dalam Penerapan Kurikulum 2013 Di Sdn 1 Watulimo. Eduhumaniora | Jurnal Pendidikan Dasar Kampus Cibiru, 11(1), 21. Https://Doi.Org/10.17509/Eh.V11i1.11905

Widana, I. W. (2020). Pengaruh Pemahaman Konsep Asemen HOTS Terhadap Kemampuan Guru Matematika SMA/SMK Menyusun Soal HOTS. Jurnal Emasains: Jurnal Edukasi Matematika Dan Sains, 9(1), 66-75. Https://Ojs.Ikippgribali.Ac.Id/Index.Php/Emasains/Article/View/618

Wijayanti, W., \& Christian Relmasira, S. (2019). Pengembangan Media Powerpoint IPA Untuk Siswa Kelas IV SD Negeri Samirono. Jurnal Penelitian Dan Pengembangan Pendidikan, 3(2), 77. Https://Doi.Org/10.23887/Jppp.V3i2.17381

Yusoff, W. M. W., \& Seman, S. C. (2018). Teachers' Knowledge Of Higher Order Thinking And Questioning Skills: A Case Study At A Primary School In Terengganu, Malaysia. International Journal Of Academic Research In Progressive Education And Development, 7(2), 45-63. Https://Doi.Org/10.6007/Ijarped/V7-I2/4120

Zulkifli, M. (2018). Analisis Bentuk Evaluasi Kurikulum 2013 Mata Pelajaran Bahasa Arab Di Mi. AlMadrasah: Jurnal Pendidikan Madrasah Ibtidaiyah, 2(2), 125-143. Https://Doi.Org/10.35931/Am.V0i0.29 